RESEARCH PAPER RP876 Part of Journal of Research of the National Bureau of Standards, Volume 16,
April 1936

\title{
OXIDATION OF WOOL: THE LEAD ACETATE TEST FOR HYDROGEN PEROXIDE BLEACHED WOOL ${ }^{1}$
}

\author{
By Arthur L. Smith and Milton Harris ${ }^{2}$
}

ABSTRACT

The lead acetate test for distinguishing between untreated and hydrogen peroxide bleached wool has been investigated. The degree of darkening of the wool during lead acetate treatments is a function of $\mathrm{pH}$, the maximum difference between untreated and bleached wool occurring at $\mathrm{pH} 5$. The results indicate that hydrogen peroxide partially oxidizes the sulfur in wool and prevents the formation of lead sulfide. A mechanism by which lead sulfide is formed in untreated wool is described.

\section{CONTENTS}

I. Introduction

II. Materials and methods

III. Results and discussion

IV. References

\section{INTRODUCTION}

Previous work $[1,2]^{3}$ has shown that in the action of hydrogen peroxide on wool, the disulfide group of the cystine is oxidized and the susceptibility of the wool to deterioration during alkali treatment is greatly increased. The extent to which the wool is oxidized bears a functional relationship to the decrease in the cystine content and to the increase in the alkali-solubility of the wool. While determinations of the cystine content or alkali-solubility of wool offer good quantitative methods for the control of hydrogen peroxide bleaching, there is a definite need for a qualitative test for distinguishing between unbleached and hydrogen peroxide bleached wool. Tests on the physical properties have been shown to be useless for this purpose [1]. Various dyeing tests $[3,4,5]$ have been used, but with only partial success since they were designed to measure damage to wool in general and lack specificity.

It is well known that under suitable conditions wool will darken when treated with solutions of lead acetate or nitrate $[6,7,8]$. More recently, this treatment has been used by Beutel and Kutzelnigg [9] to distinguish between unbleached and bleached horn and wool. Presumably, the bleached materials remain unchanged, whereas the

1 This is the second paper of a series of studies relating to the oxidation of wool.

2 Research associates at the National Bureau of Standards representing the American Association of Textile Chemists and Colorists.

8 The numbers in brackets here and elsewhere in the text refer to the numbered references at the end of this paper. 
unbleached materials are darkened by the treatment. They also found that irradiated wool was readily darkened by the lead salts, but that the same wool after oxidation did not give the reaction. The method they have outlined is unsatisfactory since it fails in the presence of small amounts of acid or alkali. For example, unbleached wool containing a little acid is not darkened, while bleached wool in alkaline solution is darkened by lead acetate.

The present investigation was undertaken to study the effect of $\mathrm{pH}$ on the darkening of wool in lead acetate solutions, and to determine the optimum $\mathrm{pH}$ for distinguishing between unbleached and hydrogen peroxide bleached wool by the lead acetate test.

\section{MATERIALS AND METHODS}

The material used for these experiments was worsted cloth, plain weave, weighing about 5 ounces per square yard, mill-processed, and ready for dyeing. It was purified by extraction with alcohol for 8 hours in a soxhlet apparatus, after which it was soaked for 1 hour in water at $140^{\circ} \mathrm{F}$. The cloth was then air-dried and cut into specimens 17.5 centimeters square.

The bleached wool was prepared from the purified worsted cloth described above by treating for 1 hour at $120^{\circ} \mathrm{F}$ with a 2-volume solution of hydrogen peroxide at $\mathrm{pH} 9.5$, centrifuging to remove excess solution, and drying for 1 hour at $140^{\circ} \mathrm{F}$. The cloth was then washed free of hydrogen peroxide and air-dried.

The alkali-treated wool was prepared from the purified worsted cloth by treating for 15 minutes at $130^{\circ} \mathrm{F}$ in a 0.5 -percent solution of sodium carbonate. This cloth was immediately washed free of alkali and air-dried.

Approximately $5 \mathrm{~g}$ of the material to be tested was boiled for 40 minutes in $400 \mathrm{ml}$ of a 0.05 -percent solution of lead acetate of known $\mathrm{pH}$, rinsed, and then dried at room temperature. The reflectance of the tested sample was measured with a Martens photometer [10].

\section{RESULTS AND DISCUSSION}

Preliminary spectrophotometric measurements at seven wave lengths in the range 405 to 703 millimicrons were made of the untreated and of the bleached cloths before and after the lead acetate treatments. The results indicated that measurements at wave lengths approximately 650 millimicrons would give a satisfactory measure of the darkening produced by the lead acetate test.

Samples of the untreated and of the bleached cloths were tested with lead acetate solutions varying in $\mathrm{pH}$ from 1 to 11 , the $\mathrm{pH}$ of the solutions being obtained by suitable additions of hydrochloric acid or sodium hydroxide. The color of the untreated and bleached cloths tested at $\mathrm{pH} 1$ was the same. The untreated cloth began to darken at about $\mathrm{pH} 2$ and the bleached at about $\mathrm{pH}$ 3.5. Between these $\mathrm{pH}$ 's and $\mathrm{pH} 11$ the samples became darker with increasing $\mathrm{pH}$. In this range the bleached samples were lighter in color than the untreated, the maximum differences occurring between $\mathrm{pH} 4$ and 5.5. At $\mathrm{pH} 11$ the color of the two materials became approximately the same. 


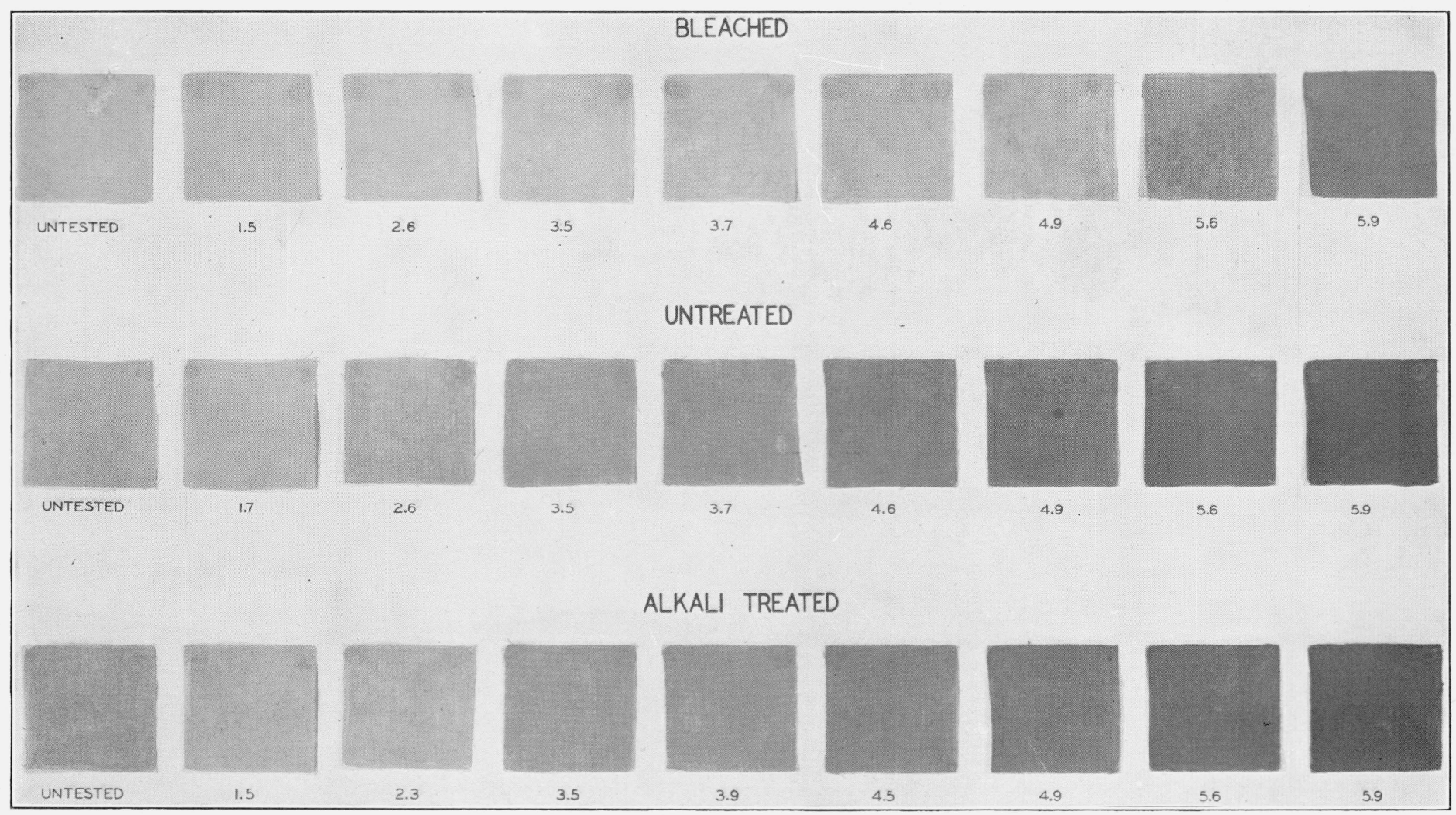

FIGURE 1.-Appearance of the bleached, untreated, and alkali-treated wool after being boiled for 40 minutes in 0.05-percent lead acetate solutions of varying $\mathrm{pH}$. 
In order to obtain a more definite maximum, and to eliminate the difficulties of regulating the $\mathrm{pH}$ with hydrochloric acid and sodium hydroxide solutions, lead acetate solutions, buffered with hydrochloric acid-sodium acetate mixtures were used [11]. A second series of untreated, bleached, and alkali-treated samples were treated with these solutions at intervals of about $0.5 \mathrm{pH}$ between about $\mathrm{pH}$ 1.5 and $\mathrm{pH} 6$. The effect of the treatments is shown in figures 1 and 2. A maximum difference in color and in reflectance at 650 millimicrons between the bleached samples and the untreated and alkali-treated samples was obtained at about $\mathrm{pH} 5 .^{4}$

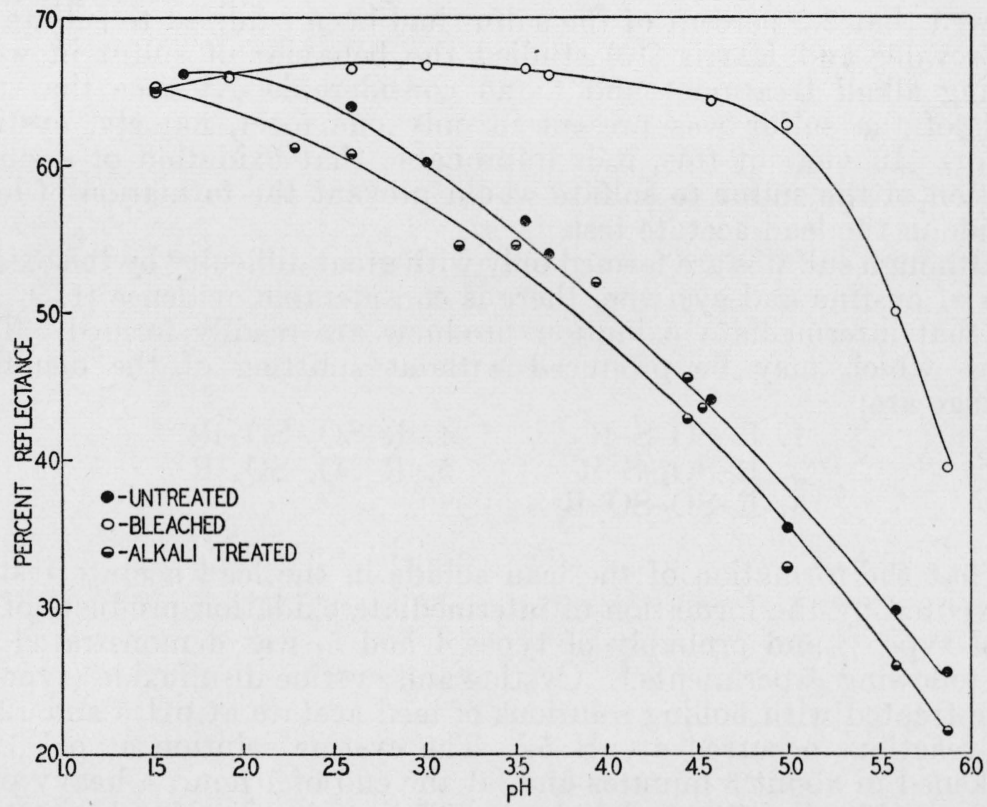

FIGURE 2.-Relation between the $\mathrm{pH}$ of the lead acetate solution and the reflectance at wave length approximately $650 \mathrm{~m} \mu$ of the tested samples shown in figure 1.

The alkali-treated samples ${ }^{5}$ are, in general, slightly darker than the untreated samples. However, the differences in reflectances between the two series of samples are of the same order of magnitude as the variations obtained in a series of like samples at a given $\mathrm{pH}$. The results, therefore, do not warrant the use of the lead acetate test as a method for the detection of alkali damage.

- Suitable buffer solutions for the lead acetate tests may be prepared according to either of the following formulas:

\begin{tabular}{|c|c|c|c|c|c|}
\hline \multicolumn{3}{|c|}{ Formula 1} & \multicolumn{3}{|c|}{ Formula 2} \\
\hline Volume (ml) & $\begin{array}{l}\text { Concentra- } \\
\text { tion }\end{array}$ & Component & Volume (ml) & $\begin{array}{c}\text { Concentra- } \\
\text { tion }\end{array}$ & Component \\
\hline 50 & $\begin{array}{r}1 N \\
2.5 \% \\
1 N \\
\end{array}$ & $\begin{array}{l}\text { Sodium acetate. } \\
\text { Lead acetate. } \\
\text { Hydrochloric acid. } \\
\text { Water. }\end{array}$ & $\begin{array}{l}200 \\
20 \\
68 \\
712\end{array}$ & $\begin{array}{r}1 N \\
2.5 \% \\
1 N \\
-\cdots\end{array}$ & $\begin{array}{l}\text { Sodium acetate. } \\
\text { Lead acetate. } \\
\text { Acetic acid. } \\
\text { Water. }\end{array}$ \\
\hline
\end{tabular}

- The alkali treatment used in this work is more severe than alkali treatments to which wool is generally exposed in practical processing. 
In their studies on keratins, Beutel and Kutzelnigg [9] postulated that during irradiation some of the sulfur in wool was converted to sulfide sulfur which readily reacted with lead salts. Since oxidation with hydrogen peroxide prevented the formation of black lead sulfide, they assumed that the sulfide sulfur had been oxidized to sulfate sulfur. It is known that in the photochemical oxidation of wool some sulfate is formed [12], but this accounts for only a small portion of the total sulfur. Furthermore, Blumenthal and Clarke [13] showed that by oxidation with bromine, only about 7 percent of the sulfur in wool was convertible to sulfate. Analyses for sulfates in the bleached samples used in this work, by the method of Mease [14], showed that 2.2 percent of the sulfur had been oxidized to sulfate.

Crowder and Harris [15] studied the behavior of sulfur in wool during alkali treatment and found considerable evidence that the bulk of the sulfur was present in only one form, namely, cystine sulfur. In view of this, it is improbable that oxidation of a small portion of the sulfur to sulfate would prevent the formation of lead sulfide in the lead acetate test.

Although sulfates are formed only with great difficulty by the oxidation of cystine and cysteine, there is considerable evidence $[1,2,16$, 17] that intermediate oxidation products are readily formed. The types which may be produced without splitting of the disulfide linkage are:
1. R-SO-S-R
4. $\mathrm{R}-\mathrm{SO}_{2}-\mathrm{SO}-\mathrm{R}$
2. $\mathrm{R}-\mathrm{SO}_{2}-\mathrm{S}-\mathrm{R}$
3. $\mathrm{R}-\mathrm{SO}-\mathrm{SO}-\mathrm{R}$
5. $\mathrm{R}-\mathrm{SO}_{2}-\mathrm{SO}_{2}-\mathrm{R}$

That the formation of the lead sulfide in the lead acetate test is prevented by the formation of intermediate oxidation products of at least type 3, and probably of types 4 and 5 , was demonstrated by the following experiments. ${ }^{6}$ Cystine and cystine disulfoxide (type 3 ) were treated with boiling solutions of lead acetate at $\mathrm{pH} 5$ and 12.5. No reactions occurred at $\mathrm{pH} 5 .^{7}$ The cystine solution at $\mathrm{pH} 12.5$ darkened in about 5 minutes and, at the end of 1 hour, a heavy precipitate of lead sulfide had formed. The cystine disulfoxide solution at $\mathrm{pH} 12.5$ remained clear during this time, and only after prolonged boiling did a slight darkening occur.

The ease with which lead sulfide is formed on the untreated wool, especially with increasing $\mathrm{pH}$, is in accord with the known lability of sulfur in wool and can be accounted for by the mechanism postulated by Crowder and Harris [15] according to the following scheme:

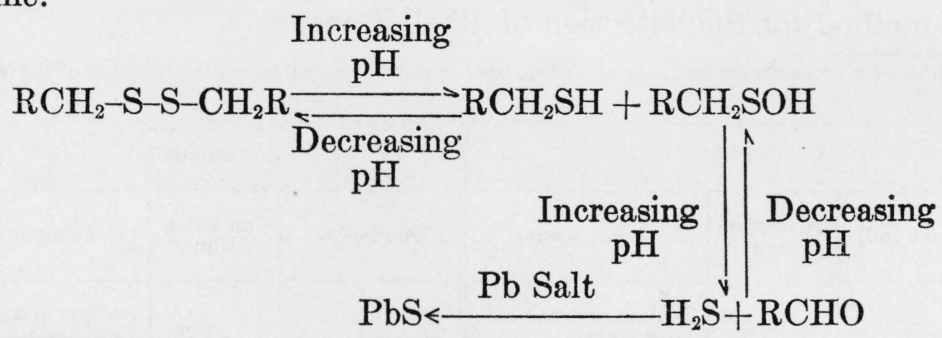

\footnotetext{
( This postulation may be made since it is known that the sulfoxides may be reduced to the sulfhydryl form, whereas the sulfones are not reduced under similar conditions.

7 The sulfur in cystine itself is very much more stable than sulfur in cystine in the wool protein.
} 
The darkening of the untreated wool samples in solutions below $\mathrm{pH} 5$ indicates the extreme lability of the sulphur. While acid tends to drive the equilibrium in the above equation in the direction shown by the arrows, the results indicate that some hydrogen sulfide ${ }^{8}$ is formed in acid solutions to about $\mathrm{pH} 2$.

\section{REFERENCES}

[1] J. Research NBS 16,-(1936) RP-

[2] J. Research NBS 15, 63 (1935) RP810.

[3] Leipzig. Monatschr. Textil-Ind. 44, 165, 211 (1929).

[4] Melliand Textilber. 9, $326(1928)$.

[5] Melliand Textilber. 12, 768 (1931).

[6] Färber-Ztg. p. 45 (1912)

[7] Die Textilfasern, Berlin, p. 90 (1928).

[8] Die Rohstoffe des Tierreiches, Berlin, p. 1094 (1932).

[9] Monatsch. Textil-Ind. 64, 183 (1934).

[10] Am. Dyestuff Reptr. 17, 49 (1928).

[11] Britton, Hydrogen Ions, p. 180.

[12] J. Research NBS. (To be published.)

[13] J. Biol. Chem. 110, 343 (1935).

[14] J. Research NBS 13, 617 (1934) RP731.

[15] J. Research NBS. (To be published.)

[16] J. Am. Chem. Soc. 56, 242 (1934).

[17] J. Biol. Chem. 105, 107 (1934).

Washington, March 5, 1936.

${ }^{8}$ In alkaline solutions, $\mathrm{Na}_{2} \mathrm{~S}$ would be formed. 